Publisher homepage: www.universepg.com, ISSN: 2707-4641 (Online) \& 2707-4633 (Print)

https://doi.org/10.34104/ijma.020.038046

International Journal of Management and Accounting

Journal homepage: www.universepg.com/journal/ijma

\title{
Usability of Z Score: A Case Study on Peoples Leasing and Financial Services Limited \& Bangladesh Industrial Finance Company Limited
}

\author{
Md. Azim ${ }^{1} *$ and Md. Jamil Sharif ${ }^{2}$ \\ ${ }^{1}$ Department of Business Administration, World University of Bangladesh, Dhaka-1205, Bangladesh; ${ }^{2}$ Department of \\ Accounting \& Information Systems, University of Dhaka, Dhaka, Bangladesh. \\ *Correspondence: azimbikrom@gmail.com (Md. Azim, M.Phil Student, Dept. of Accounting \& Information Systems, \\ University of Dhaka, Bangladesh)
}

\begin{abstract}
This study aims to identify whether or not the $\mathrm{Z}$ score is usable enough in doing prediction at the early stage of the financial distress of People's Leasing and Financial Services (PLFS) and Bangladesh Industrial Finance Company (BIFC). To predict corporate failure, Multiple Discriminant Analysis is an effective solution. Z"Score by Altman is a widely used model of multiple discriminant analysis. Using the data from 2011 to 2017 of PLFS and 2015-2017 of BIFC, this study applied the Altman Z"-Score Model as well as used SPSS software to analyze the descriptive statistics of the financial information and ratios of both company to know the level of financial distresses and attributes for reaching toward distress level. The analysis was presented in tables. The finding shows that Z"-Score by Altman is usable enough to predict the failure of the firm. The descriptive analysis shows that working capital, retained earnings, and income before interest and tax were negative which could be considered as the reasons for the distressed position. This study contributes by showing the usefulness of the $\mathrm{Z}$ score of Altman in emerging countries like Bangladesh. This is significant because early prediction can prevent liquidation which ultimately protects various stakeholders of an organization.
\end{abstract}

Keywords: Altman's Z"-Score, Liquidation, Financial distress, Predicting corporate failure, and Leasing services.

\section{INTRODUCTION}

There is a terrible situation in the sector of non-bank financial institutions in Bangladesh. Some reasons for the terrible situation are enormous anomalies in approving loans, bad internal control, lack of compliance, company rules violation, misappropriation by shareholders and directors, etc (Hasan, 2020). Recently Bangladesh government instructed the Bangladesh Bank to liquidate People's Leasing and Financial Services (PLFS) because the financial health deteriorated for the last couple of years. After liquidation, the operations of the company will be closed permanently by settling the liabilities with receiving from the sales of all assets. PLFS has failed because it was not repaying the matured funds of the depositors' money. There was a huge amount of net losses and default loans. The incident of the failure of this company came to apparent when some directors of the company run away with more than Tk 1,000 crores in 2013-2014 using counterfeit papers. That is why Bangladesh Bank removed five directors (Uddin, 2019).

If the deferred expenses and losses (Tk 1,568.65 crore) of earlier years are deducted from the assets of PLFS, then the liabilities would be greater than the assets in 2017. If the assets in 2017 are adjusted to the true amount, then the asset would be reduced by at least Tk 
1,725.3 crores from Tk 3,263.25 crores and the value of the assets would decline to $\mathrm{Tk} 1,537.65$ crores which is Tk 498 crores lower comparing to the entity's liabilities (i.e., Tk 2,036 crores). The auditor of the PLFS opined in its qualified opinion that the authority did not make any provision against the unrecoverable asset of $\mathrm{Tk}$ 1,568.66 crore in 2017. The company violated accounting standards in two cases. One case is that it showed losses (unrecoverable loans) as assets. Another case is that it deferred the interest expenses of Tk 156.64 crores and shown as other assets. Employees of PLFS claimed their unpaid salaries and other benefits before the liquidation process (NewAge, 2019). Besides PLFS, Bangladesh Industrial Finance Company (BIFC) is also in a distressed position. In the early time of 2018 , it was also facing a liquidity crisis severely due to loan scams. That is why a recommendation was sought for liquidation from the finance ministry by Bangladesh Bank (BB). But there wasn't any feedback yet from the government side (Uddin, 2019).

The Bangladesh Bank (BB) is the regulator of financial institutions. As a regulator, it took measures earlier to escape the liquidation of PLFS but those measures didn't work. The measures were:

a) After getting claims of wrongdoings, BB drove a distinct inspection and found that the company's some of the directors were taking loans illegally from it. Subsequently, PLFS's board of directors was dissolved by BB;

b) It took action against the board member of directors who committed irregularities;

c) It exerted efforts to recover the cash from the involved directors who took loans;

d) It appointed an observer to play a role in bringing fresh investors. The observer along with the company officials also tried to manage a good company for taking it over to protect the depositors' interest:

e) After failing to escape from the liquidation, it applied to Finance Ministry to wind up:

f) $\mathrm{BB}$ is going to take suitable steps to assure that the depositors will recuperate their cash shortly. In that case, small investors will get a preference in getting back the money. If there is a shortage of money after selling the company's assets, it will take steps according to relevant laws;

g) It assigned a liquidator for the PLFS by the High Court in completing the liquidation process (Islam, 2019).

It's common to be bankrupt by operational enterprises due to competitive forces in the market economy situations (Prusak, 2018). Corporate failures occur when a company fails to meet the obligation. Corporate failures also happen if prospective future cash flows are not enough to meet the obligation. Corporate bankruptcy has a bad impact on shareholders, employees, customers, creditors, and other stakeholders. So timely prediction of corporate failure is essential (Arlov et al., 2013) because timely prediction helps in taking preventive measures such as changing policies or re-organizing the operational and financial structure (Aruwa, 2007).

Early efforts in predicting corporate failure normally depended on ratio analysis. The Z-score model of Altman (1968) was the leading method in combining several weighted ratios as a multiple discriminant analysis (MDA). The model was very effective to identify whether or not a firm was probable to fail (Wilkinson, 2009). Previous studies (Al Manaseer \& Al Oshaibat, 2018; Ahmed \& Govind, 2018; Hamid et al., 2016; Boda \& Uradnicek, 2016; Zainuddin et al., 2018, Samaraweera, 2018; Csikosova et al., 2019) indicate that the Z-Score model has high prediction ability in predicting corporate failure. Since Altman Zscore is a widely used method, we need to know whether or not it useful enough to detect the failure of the PLFS and BIFC in the early stages. To know this issue, the objective of the study is to know whether or not the Z-score is usable enough to do an early prediction of the failure and/or financial distress of PLFS and BIFC.

In addition to the introduction, this study is allocated into five parts. The next part is the literature review that depicts the meaning of financial distress and corporate failure, reasons for financial distress, various models created by researchers to predict corporate failure, the widespread use of the Altman Z-score 
model. After that, the methodology shows the ways of collecting data, analyzing data, and means of presenting the analysis. Next, the findings and discussion part shows the outcome of the analysis. After that, there is a conclusion and limitation of the study. The last part comprises the implications of the study.

\section{Literature Review}

Definition of Corporate Failure - Financial distress is also known as a corporate failure, bankruptcy, default, and insolvency. Failure denotes to the lower rate of return comparing to the cost of capital of the company. Insolvency indicates the negative performance of a company for which it can't meet the debts when due. The symptom may be liquidity or cash flow shortfall. When the liabilities are higher than the asset's fair value, then it is known as financial position insolvency. In that case, the net worth of the company remains negative. As a result, the question arises whether the company will go for restructuring or liquidation. Default means when the company as a borrower violates the contract with its creditors or lenders. For example, when the company violates the agreement to maintain the stated maximum debt ratio or minimum current ratio. Such situations signal the deteriorating performance of the company. Formally a company becomes the default when it fails to pay the principal amount or the interest. In this case after the grace time (normally 30 days), the company is announced as "in default". After the grace period, if the company really fails to pay the full due, it is necessary to restructure or file for bankruptcy. A company is denoted as bankrupt if the liabilities surpass the value of assets according to the going concern concept. But it's difficult to recognize the company as bankrupt until there is a declaration by the court (Altman et al., 2019).

Financial distress means the incapability of the firm to meet financial obligations. Reasons for financial distress are excess leverage, low profitability, illiquidity, managerial inability, and other external factors such as high competition due to industry saturation, unfavorable economic situations, deregulation of industries, etc. The characteristics of distressed firms are small profits (due to increased UniversePG I www.universepg.com asset without an equivalent increase in EBIT, retained earnings, increased working capital) and meager asset productivity, etc (Gyarteng, 2019).

\section{Reasons for Financial Distress or Corporate} Failure - The reasons for financial distress is identified by Musmar (2016). They are lack of efficient leadership to progress the performance of the organization, lack of training to develop the performance of employees, and indifferent to customer satisfaction. The study by Ciccone, (2001) shows that companies with losses and unstable \& declining earnings have a robust propensity to high error and dispersion. It also finds that error \& dispersion are closely connected to financial distress. According to Ross et al. (2015), the possible events by which we can get evidence of financial distress are: not enough operating cash flows to meet the short term obligation, plunging stock price, the resignation of CEO, sackings of employees, losses, closing of plants, reduction in dividend, etc. The study of financial distress is helpful in regards to various issues like determining elements of financial distress, predicting the level of financial distress, structuring investment portfolios with the information of distressed stocks, etc (Gruszczyński, 2020). According to Couwenberg (2015), financial distress happens if a company is unable to pay its debts timely. By restructuring the assets and liabilities, the company can solve such situations. In the restructuring, the informal process (without court involvement) can be beneficial to preserve company values because it saves direct and indirect costs.

\section{Available Models to Predict Corporate Failure -} Svabova \& Kliestik (2018) state that there are various models created by researchers to predict corporate failure. They used several financial ratios or additional predictors to get an ideal bankruptcy prediction model. There are also efforts to predict the probability of bankruptcy or level of bankruptcy or distressed and non-distressed companies. In some cases, it was found that some models do not give effective results at the time and country differences. According to Samaraweera (2018), the available models during this period to predict corporate distress are Altman, Hazard \& Hybrid, K-nearest neighbor, Support vector 
machines, Decision trees, Genetic Algorithms, Fuzzy models, Bayesian models, Artificial Neural Networks, Probit, Logit, etc. The study of Agarwal \& Patni (2019) show that stakeholder can pick any model from Altman, Grover, Zmijewski, Ohlson, and Springate for bankruptcy prediction. Ashraf et al. (2019) show that comparing two models, the probit model acts accurately in prediction. They also opine that the Zscore prediction model forecasts accurately for both the early stage and advance stage of financial suffering. But traditional models for distress prediction can't perform well in the circumstances of financial disaster. Fitó-Bertran et al. (2018) find that the scoring model of Amat et al. (2016) predicts better than the scoring model of Altman for Spanish companies in detecting early stage of financial problems. Sometimes the Z-Score Model performs well and sometimes competing models outperform this model. But the results (when competing models outperformance) cannot be generalized since there is a lack of broad international comparison (Altman et al., 2014).

All the methodologies of the models to predict corporate failure can be classified into two broad groups. One is the classical group (Z-score by Altman in 1968 based on linear discriminant analysis, O-score by Ohlson in 1980 based on logit model, KMV model by Moody in 1974, Hazard model by Shumway in 2001). The Altman model and the Ohlson model are based on accounting. In contrast, the Moody model and the Shumway model are based on the market. Although these models were modified by the main researchers and other researchers, they are still widely used methods for failure prediction. Another group is the models of machine learning or data-driven methods (SVM method by Shin et al. in 2005, Ensemble boosted trees method by Zięba et al. in 2016, Neural networks method by Barboza et al. in 2017, and Ensemble learning method by Choi et al. in 2018). These methods are also known as classifiers to classify as LDA or logit (Gruszczyński, 2020).

\section{Altman's model of multiple discriminant analysis -}

Various studies (Smith \& Winakor, 1935; Merwin, 1942; Hickman, 1958; Beaver, 1966; Tamari, 1966) showed that ratio analysis is an important tool to

UniversePG I www.universepg.com predict corporate failures. But most studies cited diverse ratios which creates a problem in prediction accuracy. To mitigate the problem of univariate analysis, a Multiple Discriminant Analysis can be an effective solution for prediction because MDA combines several ratios into a significant model. But it's necessary to find which ratios are significant to predict failure and what the accepted weight would be for the ratios. MDA is one kind of statistical technique that classifies the firm into two groups (bankrupt or non-bankrupt). This model is used if there is a qualitative form in the dependent variable. After establishing the groups, this model tries to get a linear combination of the discriminating characteristics (financial ratios) between the groups for determining discriminant coefficients. Applying the actual ratios with the coefficients a base for classification exists for the groups (Altman, 1968).

The Z-score is applied significantly by both practitioners and academics. That is why it was revised several times to suit various fields in a diversity of ways. It is used by External Analytics (Advisors, Auditors, Regulators, Rating Agencies, Security Analysts, Bond \&Stock Investors, Lenders, etc.) and Research Analytics \& Internal Managers (Altman, 2018). Since there is extensive use of this model, then it is usable enough to do an early prediction of the failure and/or financial distress of PLFS and BIFC. So, the following hypothesis has been adopted: $\mathrm{Z}$ score is usable enough to do an early prediction of the failure and/or financial distress of PLFS and BIFC.

\section{METHODOLOGY}

Data have been collected from the annual reports of the companies available online. For the sample, this study selected two companies as a case study. The first one is PLFS which is going to be liquidated by the court's verdict. Another one is BIFC which has been recommended for liquidation for a long time but has not been approved. Data has been examined by the statistical package SPSS-22. The finding has been presented using tables (Table 2, 3, \& 4).

The Z-Score model predicts corporate failure correctly up to 2 years prior to distress. Hence collecting data of 
three years before failure is enough for People's Leasing and Financial Services (PLFS). But this study is conducted on the available data from the annual reports of 2011 to 2017 for PLFS and 2015 to 2018 for Bangladesh Industrial Finance Company (BIFC). The reason is to see whether PLFS was in distressed much earlier before declaring liquidation. And in the case of BIFC, although it has not been yet decided to be liquidated the financial condition is very bad according to Uddin (2019). That is why BIFC's available data were also collected for this study. Since People's Leasing and Financial Services (PLFS) and Bangladesh Industrial Finance Company (BIFC) are both Non-Banking Financial Institution (NBFI) and non-manufacturing firm, the following Z"-Score model (Altman, 1993) is applicable:

$Z^{\prime \prime}=6.56(X 1)+3.26(X 2)+6.72(X 3)+1.05(X 4)$

Here,

$\mathrm{Z}=$ Overall Score
$\mathrm{X} 1=($ Current assets-Current liabilities $) /$ Total Assets

$\mathrm{X} 2=$ Retained Earnings/Total Assets

$\mathrm{X} 3=$ Earnings before Interest and Taxes (EBIT)/

Total Assets

X4= Book Value of Equity/Total Liabilities.

Table 1: Decision Making Rules for Z-Score.

\begin{tabular}{|l|l|}
\hline \multicolumn{1}{|c|}{ Z'-Score } & \multicolumn{1}{c|}{ Decision } \\
\hline Less than 1.10 & The firm is bankrupt or failed \\
\hline Above 2.60 & $\begin{array}{l}\text { The firm is non-bankrupt or non- } \\
\text { failed }\end{array}$ \\
\hline $\begin{array}{l}\text { Between 1.10 } \\
\text { to 2.60 }\end{array}$ & $\begin{array}{l}\text { The firm is in grey zone i.e., prone } \\
\text { to be failure if protective measures } \\
\text { is not taken }\end{array}$ \\
\hline
\end{tabular}

\section{RESULTS AND DISCUSSION}

Descriptive Statistics of financial information \& descriptive analysis of the variables are shown below:

Table 2: Descriptive Statistics of Financial Information of Both Companies.

\begin{tabular}{|l|r|c|c|c|c|}
\hline & N & Minimum & Maximum & Mean & Std. Deviation \\
\hline $\begin{array}{l}\text { Current } \\
\text { Assets }\end{array}$ & 11 & $539,015,605$ & $21,211,505,176$ & $5,414,299,724$ & $7,732,829,93 \mathrm{~s} 7$ \\
\hline $\begin{array}{l}\text { Current } \\
\text { Liabilities }\end{array}$ & 11 & $7,352,763,174$ & $23,643,374,565$ & $13,845,474,261$ & $5,429,744,596$ \\
\hline $\begin{array}{l}\text { Total } \\
\text { Assets }\end{array}$ & 11 & $9,622,238,633$ & $32,859,848,900$ & $18,755,312,980$ & $8,527,060,652$ \\
\hline $\begin{array}{l}\text { Retained } \\
\text { Earnings }\end{array}$ & 11 & $(9,537,969,691)$ & $475,384,009$ & $\mathbf{( 1 , 9 8 3 , 1 5 9 , 6 9 9 )}$ & $3,512,432,826$ \\
\hline EBIT & 11 & $(883,025,245)$ & $884,128,075$ & $\mathbf{( 1 0 0 , 2 1 2 , 6 4 6 )}$ & $668,635,812$ \\
\hline $\begin{array}{l}\text { Book Value } \\
\text { of Equity }\end{array}$ & 11 & $(7,998,665,811)$ & $4,545,698,937$ & $1,215,215,264$ & $4,445,303,783$ \\
\hline $\begin{array}{l}\text { Total } \\
\text { Liabilities }\end{array}$ & 11 & $9,951,025,212$ & $29,711,352,223$ & $17,531,388,963$ & $6,744,089,712$ \\
\hline
\end{tabular}

Table 3: Descriptive Statistics of the Variables of Both Companies.

\begin{tabular}{|l|c|c|c|c|c|}
\hline & $\mathbf{N}$ & Minimum & Maximum & Mean & Std. Deviation \\
\hline $\begin{array}{l}\text { X1=(Current assets - Current } \\
\text { liabilities)/Total Assets }\end{array}$ & 11 & -1.496 & -.069 & -.60317 & .459443 \\
\hline X2=Retained Earnings/Total Assets & 11 & -.991 & .030 & -.18633 & .368208 \\
\hline X3= EBIT/Total Assets & 11 & -.091 & .057 & -.01408 & .050477 \\
\hline $\begin{array}{l}\text { X4=Book Value of Equity/Total } \\
\text { Liabilities }\end{array}$ & 11 & -.454 & .334 & .07666 & .271787 \\
\hline
\end{tabular}


Both the retained earnings and EBIT are in a negative position which indicates that the performance of the companies was not in a good position. Consequently the companies are in a distressed position (Table 2).

The mean value of working capital is negative which indicates that the net liquid assets of the companies were not enough compared to total assets. It also means that the company might be facing continuous operating losses which lead to shrunken the current assets relative to the total assets of the firm. The negative retained earnings ratio is symbolizing worse cumulative profitability. The negative EBIT ratio is indicating worse productivity of the company. This indicates that the company's earnings were not enough to cover the expenses. That is why the company needed to increase earnings to cover fixed operating expenses (Table 3).

The data analysis Table 4 showing the Z"-Score for PLFS and BIFC are as follows:

Table 4: Z"-Score Calculation using Altman Model (1993).

\begin{tabular}{|c|c|c|c|c|c|c|c|}
\hline \multirow[b]{2}{*}{ Company } & \multirow[b]{2}{*}{ Year* } & \multicolumn{4}{|c|}{ Variables } & \multirow{2}{*}{$\begin{array}{c}\text { Z"'-Score } \\
6.56(\mathrm{X} 1)+3.26(\mathrm{X} 2)+6.72(\mathrm{X} 3)+ \\
1.05(\mathrm{X} 4)\end{array}$} & \multirow[b]{2}{*}{ Position } \\
\hline & & $\mathrm{X} 1$ & $\mathrm{X} 2$ & $\mathrm{X} 3$ & $\mathrm{X} 4$ & & \\
\hline \multirow{7}{*}{ PLFS } & 2011 & $(0.459)$ & 0.0304 & 0.057 & 0.333 & $(2.18)$ & Bankrupt \\
\hline & 2012 & $(0.527)$ & 0.0272 & 0.042 & 0.334 & $(2.74)$ & Bankrupt \\
\hline & 2013 & $(0.580)$ & 0.0194 & 0.025 & 0.299 & $(3.26)$ & Bankrupt \\
\hline & 2014 & $(0.547)$ & 0.0128 & 0.024 & 0.254 & $(3.12)$ & Bankrupt \\
\hline & 2015 & $(0.262)$ & -0.0318 & $(0.029)$ & 0.142 & $(1.87)$ & Bankrupt \\
\hline & 2016 & $(0.069)$ & -0.0484 & $(0.010)$ & 0.119 & $(0.56)$ & Bankrupt \\
\hline & 2017 & $(0.074)$ & -0.0431 & 0.004 & 0.105 & $(0.49)$ & Bankrupt \\
\hline \multirow{4}{*}{ BIFC } & 2015 & $(0.597)$ & -0.0477 & $(0.027)$ & 0.090 & $(4.16)$ & Bankrupt \\
\hline & 2016 & $(0.645)$ & -0.1226 & $(0.063)$ & 0.032 & $(5.02)$ & Bankrupt \\
\hline & 2017 & $(1.378)$ & -0.8546 & $(0.091)$ & $(0.409)$ & $(12.87)$ & Bankrupt \\
\hline & 2018 & (1.496) & -0.9912 & $(0.087)$ & $(0.454)$ & (14.11) & Bankrupt \\
\hline
\end{tabular}

* Analysis was done taking data from the financial statements of Annual Reports available online.

The findings show that Z"-Scores of both PLFS and BIFC are very below from the ceiling i.e., 1.10. Both the firms are in the distress zone, i.e., both are bankrupt firms. The reasons for such situations are that both the firms' working capital was in a negative figure. The retained earning \& EBIT were in very poor amounts and most of the cases in a negative amount. The equity is also very poor. The study of Hamid et al. (2016) also indicates the same findings. Findings from both studies ratify that the $\mathrm{Z}$ score is usable enough to do an early prediction of the failure and/or financial distress of PLFS and BIFC. But the regulator or the higher-level stakeholder of the firm did not take any protective measures. As a result, the consequence is very bad for the other stakeholders (depositors, lenders, customers, employees, etc.) who are going to suffer due to liquidation.

UniversePG I www.universepg.com

\section{COCLUSION AND LIMITATION}

The analysis shows that both the companies are in a bankrupt position according to the Altman model. The study finding is similar to the study of Hamid et al. (2016). The authors took 15 out of 23 NBFI companies in Bangladesh to test whether those companies are distressed or not. The finding shows that most of the companies are in a distressed zone. Among those companies one (PLFS) is now facing liquidation that means the Altman model is usable enough to predict corporate failure. That is why the research findings should be taken seriously by the stakeholders especially the regulators. The regulator or controller of public limited companies should be aware to protect the interest of various stakeholders like depositors, lenders, customers, employees, etc. 
Otherwise, more and more companies will go out of the market.

Consequently there will be chaos in the market and economy. Hamid et al. (2016) opine that predicting financial distress is a useful tool to get early warning signal of a potential failing firm which can help the stakeholders to take effective decisions to protect probable future losses after bankruptcy. The limitation of the study is that not all the years' annual reports were analyzed due to unavailability online for which it is not sure that from when the company falls in the grey zone and/or distress zone.

\section{Implications of the study}

Since previous studies and this study show that the firms are in distressed positions, hence the concerned authority especially Bangladesh Securities \& Exchange Commission, Bangladesh Bank, Institute of Chartered Accountants of Bangladesh, Stock Exchanges should focus on the research finding. The regulators should be aware to protect the interest of various stakeholders by restructuring or any other means because liquidation brings a lot of sufferings for the associated stakeholders like the financial manager, investors, depositors, lenders, customers, employees, etc.

\section{ACKNOWLEDGEMENT}

We thank the previous authors for their contribution regarding this field of study.

\section{CONFLICTS OF INTEREST}

There is no conflict of interest regarding the publication of this manuscript.

\section{REFERENCES}

1. Agarwal A. \& Patni, I. (2019). 'Bankruptcy Prediction Models: An Empirical Comparison, International J. of Innovative Technology and Exploring Engineering (IJITEE), 8(6): 131139.

2. Ahmed M. A. R \& Govind, D. (2018). 'An Evaluation of the Altman Z-Score Model in Predicting Corporate Bankruptcy for Canadian Publicly Listed Firms', Submitted Project for the Degree of Master of Science in Finance, Faculty of Business Administration, Simon Fraser University, Canada.

3. Al Manaseer S. R \& Al Oshaibat S. D. (2018). Validity of Altman Z Score Model to Predict Financial Failure: Evidence From Jordan, International Journal of Economics and Finance, 10(8): 181- 189.

https://doi.org/10.5539/ijef.v10n8p181

4. Altman E. I (1968). 'Financial ratios, discriminant analysis and the prediction of corporate bankruptcy', The Journal of Finance, 23(4): 589-609.

5. Altman E. I. (1993). 'Corporate Financial Distress and Bankruptcy', $2^{\text {nd }}$ ed., John Wiley \& Sons, New York. USA.

6. Altman E. I. (2018). 'Applications of Distress Prediction Models: What Have We Learned After 50 Years from the Z-Score Models?', International Journal of Financial Studies, 6, 70. https://doi.org/10.3390/ijfs6030070

7. Altman E. I, Hotchkiss E \& Wang W. (2019). 'Corporate Financial Distress, Restructuring, and Bankruptcy', pp. 1-20, Hoboken, New Jersey, United States: John Wiley \& Sons, Inc. https://doi.org/10.1002/9781119541929.ch1

8. Altman E. I, Iwanicz-Drozdowska, M, Laitinen E. K, \& Suvas A. (2014), 'Distressed Firm and Bankruptcy Prediction in an International Context: A Review and Empirical Analysis of Altman's Z-Score Model'. http://dx.doi.org/10.2139/ssrn.2536340

9. Amat O, Manini R \& Renart M. A. (2016). 'Credit concession through credit scoring: Analysis and application proposal', Intangible Capital, 13(1): 51-70.

10. Arlov O, Rankov S \& Kotlica S. (2013). 'Cash Flow in Predicting Financial Distress', Advances in Environmental Science and Energy Planning, pp. 88-93.

11. Aruwa S. A. S. (2007). 'Discriminant Analysis and Prediction of Corporate Failure: A Critical Review, Finance and Accounting Research Monitor, 1(1). https://ssrn.com/abstract=1384594

12. Ashraf S, Félix E. G. S \& Serrasqueiro Z. (2019). 'Do Traditional Financial Distress 
Prediction Models Predict the Early Warning

Signs of Financial Distress?' Journal of Risk and Financial Management, 12(2), 55. https://doi.org/10.3390/jrfm12020055

13. Beaver W. H. (1966). 'Financial Ratios as Predictors of Failure', Empirical Research in Accounting, Selected Studies. pp. 71-111.

14. Boda M. \& Uradnicek V. (2016). 'The portability of Altman's Z-score model to predicting corporate financial distress of Slovak companies, Technological and Economic Development of Economy, 22(4), 532-553.

https://doi.org/10.3846/20294913.2016.1197165

15. Ciccone S. J. (2001). 'Analyst Forecast Properties, Financial Distress, and Business Risk'. 1-26. http://dx.doi.org/10.2139/ssrn.270200

16. Couwenberg O. (2015). Financial Distress, Wiley Encyclopedia of Management, 4: 1-3. https://doi.org/10.1002/9781118785317.weom0 $\underline{40039}$

17. Csikosova A, Janoskova M \& Culkova K. (2019). 'Limitation of Financial Health Prediction in Companies from PostCommunist Countries, Journal of Risk and Financial Management, 12(1), 15. https://doi.org/10.3390/jrfm12010015

18. Fitó-Bertran À, Plana-Erta D, \& Llobet J. (2018). 'Usefulness of Z scoring models in the early detection of financial problems in bankrupt Spanish companies', Intangible Capital, 14(1), 162-170.

https://doi.org/10.3926/ic.1108

19. Gruszczyński M. (2020). 'Modeling Financial Distress and Bankruptcy', In: Financial Micro econometrics, A Research Methodology in Corporate Finance and Accounting, Springer, Cham, 77-119. https://doi.org/10.1007/978-3-030-34219-7 3

20. Gyarteng K. A. (2019). 'Financial characteristics of distressed firms: an application of the Altman algorithm model', J. of Corporate Accounting \& Finance, 30(1), 63-76. https://doi.org/10.1002/jcaf.22367

21. Hamid T, Akter F \& Rab N. B. (2016). 'Prediction of Financial Distress of Non-Bank
Financial Institutions of Bangladesh using Altman's Z Score Model', International Journal of Business and Management, 11(12), 261-270. https://doi.org/10.5539/ijbm.v11n12p261

22. Hasan M. (2020). 'How ILFSL became a losing concern', Dhaka Tribune, 6th March. https://www.dhakatribune.com/business/2020/03 /06/how-ilfsl-became-a-losing-concern

23. Hickman W. B. (1958). 'Corporate Bond Quality and Investor Experience, Princeton, N. J.: Princeton University Press, USA.

24. Islam S. (2019). 'People's Leasing depositors to get back money: BB', The Financial Express, Economy Page, Retrieved from 10.5

25. Merwin C. (1942). 'Financing Small Corporations', (New York: Bureau of Economic Research).

26. Musmar F. (2016). 'Financial Distress in the Healthcare Business', Doctoral thesis, Walden University, USA.

27. NewAge (2019). 'PLFS' liabilities higher than assets: data', Retrieved from http://www.newagebd.net/article/78196/plfsliabilities-higher-than-assets-data

28. Prusak B. (2018). 'Review of Research into Enterprise Bankruptcy Prediction in Selected Central and Eastern European Countries', International Journal of Financial Studies, 6, 60. https://doi.org/10.3390/ijfs6030060

29. Ross S. A, Westerfield R. W, Jaffe J, \& Jordan B. (2015). Corporate finance, $11^{\text {th }}$ Ed., McGraw Hill Irwin, New York. USA.

30. Samaraweera A. S. A. (2018). 'A Conceptual Review of Existing Models on Prediction of Corporate Financial Distress', International Journal of Advancements in Research \& Technology, 7(7), 124-135.

http://www.ijoart.org/docs/A-Conceptual-Rev iew-of-Existing-Models-on-Prediction-of-Cor porate-Financial-Distress.pdf

31. Smith R. F., and Winakor A. H. (1935). 'Changes in the Financial Structure of Unsuccessful Corporations, University of Illinois: Bureau of Business Research, USA. 
32. Svabova L, \& Kliestik T. (2018). 'Analysis of Predictors in Bankruptcy Prediction Models for Slovak Companies', presented at 8th International Conference on the Economies of the Balkan and Eastern European Countries in the Changing World (EBEEC) in Split, Croatia, 2016, Switzerland: Springer International Publishing AG.

33. Tamari M. (1966). 'Financial Ratios as a Means of Forecasting Bankruptcy', Management International Review, 4, 15-21. https://www.jstor.org/stable/40226072

34. Uddin A. K. M. Z. (2019). 'People's Leasing faces liquidation', Retrieved from - https://www.thedailystar.net/business/news/peop les-leasing-faces-liquidation-1768792

35. Wilkinson B. (2009). 'Predicting the risk of corporate failure for Australian listed companies: A fresh approach using probability based tri-dimensional modeling, University of Wollongong, Australia.

36. Zainuddin Z, Tapa A, \& Rahim A. I. A. (2018). 'Examine the financial health of the listed technology companies in Malaysia using Altman's Z-score test'. 1, 1-8. https://doi.org/10.1063/1.5055546

Citation: Azim M. and Sharif MJ. (2020). Usability of Z score: a case study on peoples leasing and financial services limited \& Bangladesh industrial finance company limited, Int. J. Manag. Account. 2(3), 38-46. https://doi.org/10.34104/ijma.020.038046 @) 